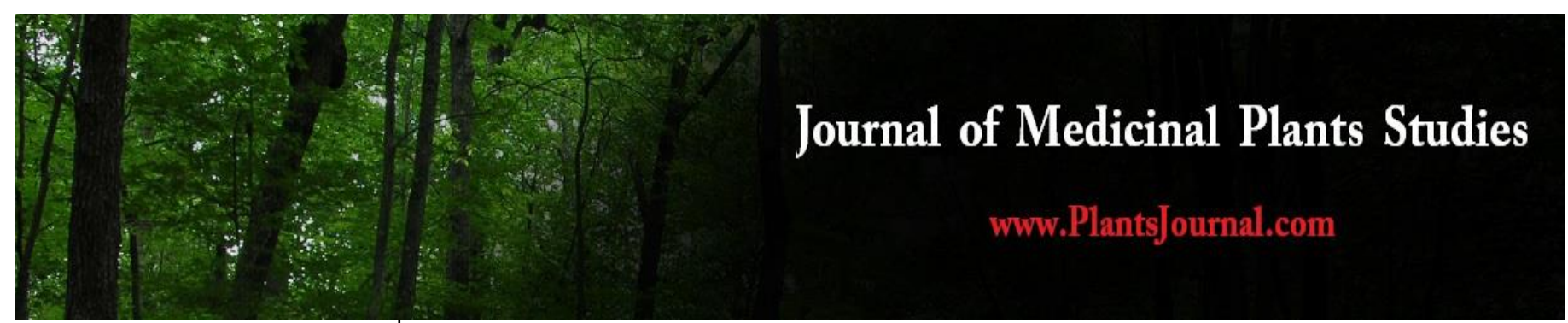

ISSN (E): 2320-3862 ISSN (P): 2394-0530

NAAS Rating: 3.53 JMPS 2018; 6(3): 112-115

(C) 2018 JMPS

Received: $20-03-2018$

Accepted: 22-04-2018

Renu Joshi

Director, Studyofplants.Com Trumbull, CT, USA

\section{A review of Fusarium oxysporum on its plant interaction and industrial use}

\section{Renu Joshi}

\section{Abstract}

Fusarium oxysporum is the causative agent of fusarium wilt which has proved to be the most destructive disease affecting a wide range of plants comprising of weeds and commercially domesticated plants and crops. The disease results in varied symptoms ranging yellowing of leaves, browning of vascular tissues, retarded growth and even plant death. Due to its soilborne nature and perennial nature of its hosts fusarium management has been a challenge. Breeding of resistant varieties is the only way that has shown some positive results in reducing the pathogen spread and increasing crop yields. Maintenance of the field hygiene is also advocated in the management of Fusarium oxysporum. Along the breeding of resistant varieties, a suitable integrated pest management should be researched on to reduce these heavy losses as a result of fusarium wilt. Despite of the negative impact of Fusarium in the field crops, the fungi can be beneficial in the food and alcoholic industries as it can produce enzymes such as pectinase and cellulase.

Keywords: Fusarium oxysporum, interaction and industrial use.

\section{Introduction}

Fusarium oxysporum is a pathogenic soil borne ascomycete fungi affecting many plants in the world by causing fusarium wilt, which is a lethal vascular syndrome in plants (Flood) ${ }^{[8]}$. According to Thomas Gordon, there are over 100 host- specific species (formae soeciales: ff. spp) of Fusarium oxysporum of which they are widely distributed around the world (26). Commercially $F$. oxysporum strains infect, cause disease symptoms and kill a wide range of plants for instance the Solenaceae group comprising of tomatoes, potatoes, pepper, and egg plants. They also affect other plants such as palm oil, legumes, strawberries, sugarcane lettuce, Watermelon and Bananas (335-339). The pathogen produces asexuality through spore productions. The spores can remain in the dormant state in the soil for as long as 30 years a factor which makes it difficult to control (335-339).

The pathogen can be dispersed from one area to another through a number of ways which include; moving of infected planting materials and seeds, farm tools and machinery especially when used in the infected soils and later used in healthy fields. Air and water also plays a role in the spread of this fungus (Gamliel-Atinsky, E., et al. 160-166) ${ }^{[15]}$. Though fusarium has wide range of host plants, the formae speciales are host specific. For instance, F. sp. cubense is specific to banana, F. sp. phaseoli for Beans, f. sp. cucumerinum for cucumbers, F. sp. Cepae for onions, F. sp. passioflorae for passion fruits, F. sp. Lycopersici for tomatoes and Fusarium oxysporum. f. sp. elaeidis for palm oil.

The fungal pathogen affects the plants by producing macro and micro conidia that infect the roots of the plants feeding and infecting the vascular tissues leading to wilting and gradual death of the plants (Chung) ${ }^{[5]}$. The disease fusarium wilt caused by Fusarium oxysporum shows symptoms like wilting during the day, stunted grow and leaf chlorosis while the internal symptoms of the affected vascular tissues become brownish or black in colour (Chung) ${ }^{[5]}$. The pathogen is destructive and has been reported to cause huge field crop loses. For instance, in South Africa alone between 2008 and 2009 maize yield loss as a result of fusarium was estimated to be above 12 million metric tonnes (Gerber 16). A research by Gait Fee Chung, ${ }^{[5]}$ reported that over $25 \%$ of oil palm yield loses in Zaire is as a result of fusarium wilt. 


\section{Host Pathogen Interaction}

Fusarium oxysporum is a parasitic pathogen that interacts with the host plants resulting to development of fusarium wilt disease. These fungi depend on plants for nutrients and have developed mechanisms that enable then to get into the plants. Some of the penetration mechanisms that have been studied and identified by scientist include structural morphology adjustment for instance hyphae development. Other means is the physiological changes which involve production of enzymes to aid in penetration. The Fusarium oxysporum develop hyphae that in attachment and penetration of the epidermal cells of both the wounded and un-wounded roots (Mendgen, Hahn and Holger Deising) ${ }^{[15]}$. The fungi also produce cell wall degrading enzymes such as cutanase and pectinase and polygalacturonase to aid in penetration (Mendgen, Hahn and Holger Deising) ${ }^{[15]}$.

Once in the roots, they colonize the root cells and spreads to other parts of the plants through the vascular bundles and with the help of upstream flow of water also called the transpiration stream pull of water in the vascular tissues specifically the xylem. The fungus grows and produces micro and macro conidia while spreading in the vascular tissues (Bishop and Cooper) ${ }^{[4]}$. The mycelia growth in the vascular growth leads to blockage of the vessels thus resulting to water stress and development of wilt symptoms. The process is accelerated as the plants try to respond by producing defence factors such as tyloses, gels and proliferation of the parenchyma cells resulting to further blockage of the vessels (Emiro, Ortiz et al. $)^{[17]}$.

Resistant plants try to counter the spread of the fungi by producing antifungal compound such as tyloses, gels and gums to inhibit the growth and spread of the fungi. Early productions of the antifungal compounds before the fungi reach the stem vessels may enable the plant to survive but without symptoms. In susceptible plants, production of antifungal compounds is very slow compared to fungal growth hence development of symptoms.

\section{Disease development and symptoms}

Fusarium wilt is a warm weather soilborne fungal disease that does optimally at temperatures of about $28^{\circ} \mathrm{C}$. Temperatures above $34^{\circ} \mathrm{C}$ or below $17{ }^{\circ} \mathrm{C}$ retard the disease development. Fusarium wilt disease afflicts various crops ranging from commercial legumes, tomatoes, melons maize, bananas and oil palms among others. The disease has been reported in many regions of the world for instance in the United states of America where it was first reported in 1930 in melon plants and later spread to Canada in 1945 (Zitter, 1) ${ }^{[21]}$. The disease starts with the fungal pathogen penetrating into the plant roots and colonizing the vascular tissues (Bishop and Cooper) ${ }^{[4]}$.

The fungi produce hyphae to attach to the root surface, produce cell wall degrading enzymes to break the cell wall and allows the hyphae mycelium to grow through the cortex into the vascular vessels (phloem and xylem) (Mendgen, Hahn and Holger Deising) ${ }^{[15]}$. Fusarium wilt becomes evident once the fungal pathogen Fusarium oxysporum has colonised and spread to various parts of the plant and causing blockage of the vessels as a result of mycelia growth. The plants also produce antifungal compounds that contribute to vessels blockage in the process of trying to inhibit fungal spread (Emiro, Ortiz., et al.) ${ }^{[17]}$. Vascular vessel blockage and nutrient absorption leads to acute disease development and symptoms. Fusarium disease occurs in two forms also called syndromes. The first form of the disease manifestation is the "acute wilt" a case where the plants leaves dry out very quickly and die while attached to the original position while the second form of the syndrome is the "chronic wilt" where the plants lives with the fungi for a longer period which can even proceed to years. In chronic will syndrome, the plants remain stunted (Flood) ${ }^{[8]}$.

The fungi affect the plants at any stage and some of the symptoms that are exhibited include root rots and damping off in young plants, marginal yellowing and sometimes full chlorosis on leaves of mature plants (Zitter 2) ${ }^{[21]}$. The fungi also affect the plants leading to gradual stunted growth of the plants over time (Flood) ${ }^{[8]}$. Internal discoloration of the vascular bundles is the main symptom that is used as a diagnostic measure for fusarium wilt. Production of gummy red ooze from the lesion is another common symptom of fusarium wilt but according to various reviews on the symptoms this should not be mistaken with ooze as a result of stem blight (Zitter 2) ${ }^{[21]}$. In some rare occasions fusarium wilt has been associated with sudden collapse of some plants.

\section{Epidemiology}

Epidemiology is the mode or a way in which a disease or a pest is spread from one place to another or transmission from one organism to another. Fusarium oxysporum is a soil borne fungal pathogen and its spread is mainly facilitated through contact with infected plant parts which can also be seeds (Flood) ${ }^{[8]}$. Farm cultivation tools and machinery contributes to high percentage of pathogen locomotion from one field to another especially when the implements are used in an infected field and hygiene of the implements is not checked before using them in another clean field. The pathogen can be dispersed from one area to another through a number of ways for instance infected planting materials and seeds are the most common method of spread and allows long distance spreading of the disease (Wong) ${ }^{[20]}$. Air and water also plays a role in the spread of this fungus especially floods and irrigation water.

Environmental and soil factors are crucial for plant infection and disease manifestation. From different research the effects of fusarium wilt are high in soil infected with nematodes. The disease is also enhanced by the presence of phosphorus and ammonium nitrogen and slightly acidic soils (Wong) ${ }^{[20]}$. The disease severity has been found to be optimum at $28{ }^{\circ} \mathrm{C}$ and retards at temperature above $34^{\circ} \mathrm{C}$ and below $17^{\circ} \mathrm{C}(\text { Zitter } 2)^{[21]}$.

\section{Geographical Distribution}

Fusarium oxysporum is a fatal soilborne fungus that has been in most agricultural fields around the world. The pathogen has more than 100 strains (formae speciales: ff.spp) and having several hosts ranging from herbaceous plant to trees (Gordon 26). The distribution of this fungi is as wide as the distribution of its host plants. For example, three races of Fusarium oxysporum $\mathrm{f}$. sp. lycopersici race 1 one having been reported to exist almost all over the world, while race 2 has been specifically reported in Ohio, Florida, brazil, Netherlands, Britain, Mexico, Australia, Morocco Israel and Iraq. Race 3 has been reported in Brazil, Australia, California and Florida (Wong) ${ }^{[20]}$. Fusarium solani f.sp. Cucurbitae, a fusarium species that mainly affects Cucurbitaceae family has been reported in most regions of the world mainly in the tropics. A survey by Zitter, ${ }^{[21]}$ done on Fusarium solani f.sp. Cucurbitae distribution in New York showed three races 1,2 and 3. Race 1 was found in Washington county, race 2 was reported in Washington, Niagara county, Schohare, Colombia and Rensseler. Fusarium oxysporum f.sp albedinis has been reported mainly in African countries; Algeria, Mauritania and 
Morocco. Fusarium oxysporum f. sp. Cubense has been reported in banana fields in various countries including, Asia, Australia, Philippines, Zimbabwe, South Africa, Nigeria, Pakistan, China, Costarica, Kenya, and Uganda (Diane, Mostert., et al. 2-3).

\section{Management of fusarium and fusarium wilt}

Fusarium oxysporum is a soilborne pathogen and is able to stay dormant in the soil for several seasons (Flood 661). This ability to stay in a dormant manner and existence of perennial host plants has contributed to the difficulty for its control. Several methods have been used to try and manage the spread of this devastating fungus. Some of the methods that have been put in place include field sanitation which currently is the best method of control. It is advocated that only certified and pathogen free seed be used. Farm tools should be clean and sterilized before use on a healthy field. Cultural practices such as complete removal and destruction of infected plants is another possible way of controlling the fungal pest (Renard and Quillec) ${ }^{[18]}$. Though many scientists have argued this is not the best especially in orchards and other trees where there is possibility of the roots intertwining below the soil surface. Fusarium has been found to thrive in presence of phosphorus and high nitrogen with slightly acidic soils. To counter this, application of potassium and soil liming is done to make the conditions unfavourable to the fungus (Flood 661). Crop rotation with a non-host crop for more than four seasons has also shown to yield some positive results to the control of Fusarium oxysporum. Other methods that have been employed to control fusarium are soil solarisation and sterilization. Use of fungicides to fumigate the soils is another way but is facing challenges due to existence of fusarium species that are symptomless. The most effective way of managing this menace is use of resistant varieties (Corley and Tinker 135-137). Breeding of resistant varieties have yielded positive results for instance the use of resistant oil palms to fusarium showed an increase in yield for about $25 \%$ (Franqueville and Renard 403)

\section{Industrial Use}

Microorganisms have gained great importance in food industry mainly in food microbiology and biotechnology (Izabel, Soares., et al.) ${ }^{[19]}$. Microorganisms are used in the food industry to undertake the process of fermentation mainly in production of dairy product s such as cheese and yogurt, preparation of alcoholic beverages, organic acids, ethyl alcohol and some drugs (Izabel, Soares., et al.) ${ }^{[19]}$. With the advent of the modern biotechnology, enzyme industry has mushroomed strongly resulting in quick growth of food biotechnology. The enzymes from various microorganisms are used in production of some food products for instance vinegar, wine, cheese and beer. Some of the microorganisms have been used in drug formulation (Kirk et al.) ${ }^{[13]}$. Most of the enzymes are currently used in various industries for hydrolytic purposes to break down natural organic compounds (Kirk et al. $)^{[13]}$.

\section{Fusarium enzymes for industries Enzyme Pectinase}

Like other fungi, bacteria and yeast, fusarium produce enzyme pectinase majorly used in the food industries to help in fruit ripening, treatment of grape juice for wine making, tomato pulp extraction, tea and chocolate fermentation and fibre degumming (Almeda 1941-1942). Enzyme pectinase is used in industries to enhance scent and volatile compounds in fruits and vegetables as well as concentrating antioxidants in virgin oil (Izabel, Soares., et al.) ${ }^{[19]}$.

\section{Enzyme Cellulase}

Fusarium is one of the producers of enzyme cellulase which is used as a hydrolytic compound in the food, cosmetic, drug, paper, textile and detergent industries. Cellulase is also used in the production of orange vinegar and clarification of citrus juice. Like pectinase enzyme cellulase can be use in the wine industry (Soared et al., 86).

\section{Biological Control Agent}

Fusarium oxysporum has been known to be a biological control agent against Cannabis sativa with the aim of controlling marijuana cultivation (McPartland John, M., et al. 74). Fusarium oxysporum has been associated with biocontrol mechanisms against striga weed (Ciotola, Di Tommaso, and Watson 129-145) ${ }^{[6]}$ though this was disputed by Avedi et al, (10-12).

\section{Impacts on food productions and health}

Fusarium is a devastating fungi to major crops in the world leading to the decline in food production. Some of the fusarium species have been associated to cause allergens for humans for instance; Fusarium solani is allergenic affecting $4 \%$ of nasobronchial allergy patients.

\section{Conclusion}

Fusarium oxysporum is a serious pest affecting various crops in the world. It is the causative agent of fusarium wilt, a major fungal disease devastating many crops and leading to huge loses around the world. Many ways have been formulated to try and manage the spread of the fungus but have proven to be difficult because of its ability to remain in a dormant state for a long period in the soil, existence of perennial host and its wide range of hosts. Field hygiene and breeding of resistant varieties have remained the only possible way of managing losses as a result of the fungal infection. From this review, it is recommended that a possible integrated pest management technique be sought to try curbing the spread of this fungus and its resultant losses in crop production.

\section{References}

1. Almeida Catarina et al. Use of two different carriers in a packed bed reactor for endopolygalacturonase production by a yeast strain. Process Biochemistry. 2005; 40(5):1937-1942.

2. Hacer Handan. Fusarium species isolated from common weeds in eggplant fields and symptomless hosts of Fusarium oxysporum f. sp. melongenae in Turkey. Journal of Phytopathology. 2013; 161(5):335-340.

3. Avedi Edith K et al. Fusarium oxysporum f. sp. strigae strain Foxy 2 did not achieve biological control of Striga hermonthica parasitizing maize in Western Kenya. Biological control. 2014; 77:7-14.

4. Bishop CD, Richard Cooper M. An ultrastructural study of vascular colonization in three vascular wilt diseases I. Colonization of susceptible cultivars. Physiological Plant Pathology. 1983; 23(3):323-343.

5. Chung Gait Fee. Effect of Pests and Diseases on Oil Palm Yield. Palm Oil. 2012, 163-210.

6. Ciotola M, DiTommaso A, Watson AK. Chlamydospore production, inoculation methods and pathogenicity of 
Fusarium oxysporum M12-4A, a biocontrol for Striga hermonthica. Biocontrol Science and Technology. 2000; 10(2):129-145.

7. Corley RHV, Tinker PB. Selection and breeding. The oil palm. 4th ed. Oxford: Blackwell Science Ltd Blackwell Publishing, 2003, 133-200.

8. Flood Julie. A review of Fusarium wilt of oil palm caused by Fusarium oxysporum f. sp. elaeidis. Phytopathology. 2006; 96(6):660-662.

9. Franqueville de H, Renard JL. Improvement of oil palm vascular wilt tolerance: results and development of the disease at the R. Michaux plantation. Oleagineux. 1990; 45(10):399-405.

10. Gamliel-Atinsky E et al. Inoculum availability and conidial dispersal patterns of Fusarium mangiferae, the causal agent of mango malformation disease. Phytopathology. 2009; 99(2):160-166.

11. Gerber Johan. Yield response of Fusarium infected maize seed treated with biological control agent formulations. Diss. 2010.

12. Gordon Thomas R. Fusarium oxysporum and the Fusarium wilt syndrome. Annual review of phytopathology. 2017; 55:23-39.

13. Kirk Ole, Torben Vedel Borchert, Claus Crone Fuglsang. Industrial enzyme applications. Current opinion in biotechnology. 2002; 13(4):345-351.

14. McPartland John M, Karl Hillig W. Cannabis clinic Fusarium Wilt. Journal of Industrial Hemp. 2004; 9(2):67-77.

15. Mendgen Kurt, Hahn M, Holger Deising. Morphogenesis and mechanisms of penetration by plant pathogenic fungi. Annual review of phytopathology. 1996; 34(1):367-386.

16. Mostert Diane et al. The distribution and host range of the banana Fusarium wilt fungus, Fusarium oxysporum $\mathrm{f}$. sp. cubense, in Asia. PloS one. 2017; 12(7):e0181630.

17. Ortiz Emiro et al. Histopathological features of infections caused by Fusarium oxysporum and F. solani in purple passionfruit plants (Passiflora edulis Sims). Summa Phytopathologica. 2014; 40(2):134-140.

18. Renard JL, Quillec G. Fusarium and replanting. Elements to be considered when replanting oil palm in a Fusarium zone in West Africa [Ivory Coast]. Oleaginous. 1983; 38:421-427.

19. Soares Izabel et al. Microorganism-produced enzymes in the food industry. Scientific, Health and Social Aspects of the Food Industry. InTech, 2012, 83-95.

20. Wong Mui-Yun. Fusarium oxysporum f. sp. lycopersici (Sacc.) WC Snyder and HN Hans. Soilborne Plant Pathogen Class Project, [cit. 201009-1O] 2003, 728.

21. Zitter Thomas A. Fusarium diseases of cucurbits. 1998, $1-4$. 